\title{
Apology Strategies in the Interethnic Communication of Bicultural Fiction with \\ Reference to Zadie Smith's Novel White Teeth
}

\author{
Eman Taher Othman
}


Apology Strategies in the Interethnic Communication of Bicultural Fiction with Reference to Zadie Smith's Novel White Teeth Eman Taher Othman

مجلة وادي النيل للاراسات والبحوث الإنسانية والاجتماعية والتربوية (مجلة علمية محكمة)

Apology Strategies in the Interethnic Communication

of Bicultural Fiction with Reference to Zadie Smith's

Novel White Teeth

Eman Taher Othman ${ }^{(*)}$

\begin{abstract}
:
This study has attempted to provide a socioprgmatic analysis of the interethnic communication between the British and the Bangladeshis in Zadie Smith's novel White Teeth. The speech act of apology is the object of the present study. This study tries to illustrate whether the speech act of apology, for example, is able to maintain the harmony and restore the interaction balance between the British and the Bangladeshis.In order to answer the research question set forth for this study, the data collected were analyzed both qualitatively and quantitatively. The qualitative analysis is carried in terms of what kinds of strategies speakers use most often when apologizing. Consequently, a number of basic categories of apologies have been set in order to analyze the data. The categories are adapted from Olshtain and Cohen (1983). The examples are taken from the collected data. The quantitative analysis allows for a more in depth look at the different strategies that speakers use in order to apologize in different situations. Therefore, an attempt at finding the frequency of different types of apologies in the three novels is done.
\end{abstract}

Key words: communication-apology-strategy -White TeethZadie Smith-analysis.

$$
\begin{aligned}
& \text { (*) أ. إيمـان طـاهر عثــان: مدرس مسـاعد- بقسم اللغـة الإنجليزيـة- كلية الآداب بالوادي } \\
& \text { الجديد- جامعة أسيوط. } \\
& (1)
\end{aligned}
$$


مجلة وادي النيل للاراسات والبحوث الإنسانية و الاجتماعية والتربوية (مجلة علمية محكمة)

(ISSN : 2536 - 9555)

\subsection{Introduction}

This study has attempted to provide a socioprgmatic analysis of the interethnic communication between the British and the Bangladeshis in Zadie Smith's novel White Teeth. The speech act of apology is the object of the present study.A number of basic categories of apologies have been set in order to analyze the data. The categories are adapted from Olshtain and Cohen (1983). The subcategories of each strategy will be applied as well.

\subsection{Definition of the Speech Act of Apology}

Definitions of the speech act of "apology" are subject to much discussion. Partridge (1977) traces the term apology to its root "apologos" "a story," from which "apologia," an oral or written defense became "apology." Goffman (1972: 138) views apologies as "remedial exchanges that indicate an acceptance of responsibility by the speaker, and serves as an implicit selfjudgment against the speaker".In addition, Homles (1990: 155) defines apologies as "social acts conveying affective meaning", and he believes that "apologies have been seen as negative politeness strategies aimed at remedying the effects of an offence or a facethreatening act and restoring social harmony and equilibrium" (Ibid:184). Davies, Merrison andGoddard (2007: 41) further elaborate that apologies" strengthen the offender's membership of the community and seemto enhance its social standing because apologies mirror the apologizer's understanding and acceptance of the ruleviolated by the offense and pay face to the addressee, thus paying back the debt of any violation or gaining credit for thefuture."

Moreover, Marquez-Reiter (2000: 44) identifies an apology as "acompensatory action for an offense committed by the speaker which has affected the hearer."Finally, Lazare (2004: 23) presents a comprehensive definition of the term 'apology'. By this 
Apology Strategies in the Interethnic Communication of Bicultural Fiction with Reference to Zadie Smith's Novel White Teeth Eman Taher Othman

مجلة وادي النيل للاراسات والبحوث الإنسانية والاجتماعية والتربوية (مجلة علمية محكمة)

definition, Lazareexplains the process in which both the offended and the offender experience the act of apology. He says that

"apology" refers to an encounter
between two parties in which oneparty,
the offender, acknowledges
responsibility for an offence or grievance
and expresses regret or remorse to a
second party, theaggrieved. Each party
may be a person or a larger group such
as a family, a business, an ethnic group, a
race, or a nation. The apology may
beprivate or public, written or verbal,
and even, at times, nonverbal.

In performing the act of apologizing, the offender needs to employ a certain strategy of apology. Many researchers have devised different taxonomies for apology strategies (e.g. Fraser (1981), Owen (1983), Olsthain and Cohen (1983), Bergman and Kasper (1993) Trosborg (1994), Holmes (1995), Brown and Attardo (2000) Deuteschman (2003), Nureddeen (2008)). In this study, the apology strategies were adapted fromOlshtain and Cohen's (1983) taxonomy.

\subsection{Apology Strategies in White Teeth \\ 1.2.1. Expression of Apology}

This strategy involves apologizing explicitly by means of an illocutionary force indicating device (IFID) such as (be) sorry, apologize, regret and excuse.The sub-categories of this strategy include "expression of regret," "offer of apology," and "request for forgiveness." 
مجلة وادي النيل للاراسات والبحوث الإنسانية و الاجتماعية والتربوية (مجلة علمية محكمة)

(ISSN : 2536 - 9555)

\subsubsection{Expression of Regret}

In their interaction with each other in White Teeth, the British and the Bangladeshis make use of "expression of regret."

(1) "He's a register, Archibald, you old flake," said his friend Samad, "Not a catholic priest."

"Right.Of course.Sorry. Nervous."(White Teeth, P. 42)

(2)"Put that away."

"I have been thinking that I am buggered, Lieutenant Jones. I see no future. I realize this may come as a surprise to you - my upper lip, I'm afraid, is not of the required stiffness. But the fact remains. I see only blackness."(White Teeth, P. 94)

(3) "It's just .... It's Ms. Miniver. All evening you've been ... and it's, umm ... actually not Mrs. It's Ms. Ms."

"I'm sorry? You are not married?"

"Divorced, actually, yes divorced. I'm keeping the name."

"I see. You have my condolences. Miss Miniver, now, the matter I --- "

"I'm sorry," said Katie, pulling her fingers through her intractable hair. "Umm, it." "Umm, it's not Miss, either. I'm sorry, I have been married you see, so-"(White Teeth, P. 107)

In the previous extract, some of the apologies included in the category of "expression of regret" contain lexical items that make the expression of apology explicit, such as "Sorry," and "afraid".In extract (1), for example, Archibald apologizes to Samad using the lexical item "sorry". He apologizes for calling the register who does the registration of the marriage a catholic priest. In example (2), Samad apologizes to Archibald using the lexical item "afraid".Samad refuses to put the gun away. He sees no future and his lipis not of the required stiffness. He sees only blackness. In example (3), Samad apologizes to Miniver using the lexical item "afraid".Samad calls Miniver at the scool meeting MrsMiniver. She wants him to call her Ms. because she isn't married.

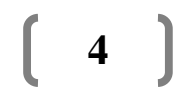


Apology Strategies in the Interethnic Communication of Bicultural Fiction with Reference to Zadie Smith's Novel White Teeth Eman Taher Othman

مجلة وادي النيل للار اسات والبحوث الإنسانية والاجتماعية والتربوية (مجلة علمية محكمة)

\subsubsection{Offer of Apology}

To provide a remedy for the offence they commit, the British and Bangladeshis make use of "offer of apology." Consider, for example, the following, extracts:

(1) "There is always Jesus."

"But I can't very well say" I'm ho Jesus"... I mean, obviously

I'm not." "Meaning you are not a good person?"

"I like to think I'm not all bad."

"And that is enough?"

"Well ... I ...."

"Oh my dear, I apologize ..." began Samad. "I was not being serious Miss Burt-Jones."(White Teeth, P. 131)

The previous extract shows that the offender makes use of one of the set of formulaic, routinized performative verbs "apologize" to express his apology. Here Samad apologizes to Poppy HurtJones for describing himself as a bad man."An offer of apology,"according to Holmes (1990), is usually the first and most direct manner of expressing remorse.

\subsubsection{Request for Forgiveness}

In their interaction with each other in the White Teeth, the British and Bangladeshis make use of "request for forgiveness." Consider, for example, the following extracts:

(1) "I have known the old boy since-when?"

"1945, Sam." "Then it's your mission to make him happy if he is not. And he wasn't! quit the opposite until you made an appearance!

Wallowing in the shit-heap, if you will pardon the French."(White Teeth, P. 43) 
مجلة وادي النيل للاراسات والبحوث الإنسانية و الاجتماعية والتربوية (مجلة علمية محكمة)

(ISSN : 2536 - 9555)

(2) "Look like hell!" snorted Gozan's nephew "Everything looks like hell!" drunkenly scrambling through one such set of roots.

"Pardon him. He feels strongly because he is young-Lieutenant Jones." said Gozan. (White Teeth, P.92)

(3)"Oh, it is much too important to be delayed, Mrs. Miniver. Now, if I can just -"

"Ms. Miniver."

"Pardon me?" "It's just .... It's Ms. Miniver. All evening you've been ... and it's, umm .... Actually not Mrs. It's Ms. Ms.(White Teeth, P. 107)

In the previous extracts, the lexical items that belong to this category and that the apologizers choose to make use of are "pardon" and "excuse." In example (1), Samad apologizes to Archibald using the lexical item "pardon".Samad apologizes for his inability to speak French well.In extract (2), Gozanapologizes to Lieutenant Jones for the bad behavior of his nephew. In extract (3),Samad apologizes to Miniver using the lexical item "pardon".Samad calls Miniver at the school meeting Mrs. Miniver. She wants him to call her Ms.because she isn't married.

\subsubsection{Explanation or Account of Situation}

When speakers make use of apology, they provide a justification, trying to give an explanation of why the situation that required the apology happened. Data analysis has shown that such an explanation may be explicitly related to the offence as it can be seen in the following extracts:

(1) "He's a register, Archibald, you old flake," Said his friend Samad, "Not a catholic priest."

"Right.Of course. Sorry. Nervous."(White Teeth, P.42)

(2) "I see. And are there many pagans, Mrs. Owens, at Manor School?"

"Pagan-I'm afraid I don't understand."

"It is very simple. The Christian calendar has thirty - seven

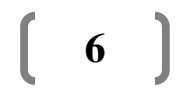


Apology Strategies in the Interethnic Communication of Bicultural Fiction with Reference to Zadie Smith's Novel White Teeth Eman Taher Othman

مجلة وادي النيل للار اسات و البحوث الإنسانية والاجتماعية والتربوية (مجلة علمية محكمة) religious events. The Muslim calendar has nine ...And the first festival that must go, in my opinion, is this Harvest festival business."

"I'm afraid," said Mrs. Owens, " removing Christian festivals from the face of the earth is a little beyond my jurisdiction."(White Teeth, P.107)

(3) "Mill!"

"Not tight now, Jones."

"But Mill!"

"Please, Jones. This is Hifan. Oldfriend.I'm trying to listen to him."

"Mill. Mill. 's important." (White Teeth, P.244)

As it is obvious in the previous extracts, speakers provide a justification, trying to give an explanation of why the situation that required the apology happened. Such explanations are explicitly related to the offence. In extract (1), for example, Archibald apologizes to Samad for calling the register who does the registration of the marriage a catholic priest. He justifies his apology on the ground that he is nervous. In example (2), Mrs. Owensapologizes to Samad for her inability to understand Samad's observation that there many pagans at Manor School. Mrs. Owensalsoapologizes to SamadIqbal for the refusal of his demand concerning the removing of Christian festivals. She justifies her apology on the ground that removing Christian festivals from the face of the earth is a little beyond her jurisdiction. In extract (3), Mill apologizes to Miss Jones. He is unable to listen to her. He is busy listening to his old friend, Hifan.

Data analysis has also revealed that such explanations may present the "state of affairs" in a general way, thus relating implicitly to the offence as it can be seen in the following extracts:

(1) "You play like a faggot," said Samad

"I'm old," said Archie, throwing his cards "in," I'm old. Who'd haveme now?(White Teeth, P.10) 
مجلة وادي النيل للاراسات والبحوث الإنسانية و الاجتماعية والتربوية (مجلة علمية محكمة)

(ISSN : 2536 - 9555)

(2) "Why don't you eat it?" said Archie. "Strong business, if you ask me." "Why's that?" said Archie, passing from his feast "It's in our cultures, my friend." He thought for a minute.

"Maybe deeper.Maybe in our bones."(White Teeth, P. 81)

(3)"My dad was in the war. He played for England," piped up

Millat. $\quad$ "I'm afraid you must be mistaken," said Mr.

Hamilton. "There

remember."(White Teeth, P. 140)

As it is obvious in the previous examples,speakers try to give an explanation of why the situation that required the apology happened. Such explanations are implicitly related to the offence. In example (1), Archie apologizes to Samad for playing in a bad way. He gives a justification that he is an old man. In example (2), Samad apologizes to Archie for not eating meat delivered from pigs. It's forbidden in his culture to eat such kind of meat. In example (3), Mr. Hamilton apologizes to Millat because Milliat's father doesn't participate in the war.He gives a justification that there were certainly no wogs in the war.

\subsubsection{Acknowledgment of Responsibility}

The subcategories of this category are "accepting the blame," "expressing self-deficiency," "recognizing the other person as deserving apology" and "expressing lack of intent".

\subsubsection{Accepting the Blame}

Consider the following extracts

(1)"Stonebridge Estate?" Samad had asked.

"No-but not far from there. Do you want to meet up?"

"Yes. Oh, damm it! Yes."

And then he had kissed her again... Then they had the short, obligatory exchange that those who cheat have to make them feel less like those who cheat.

"I really shouldn't..."

"I'm not at all sure how this-"

"My wife... my children..." (White Teeth, P. 138) 
Apology Strategies in the Interethnic Communication of Bicultural Fiction with Reference to Zadie Smith's Novel White Teeth Eman Taher Othman

مجلة وادي النيل للاراسات والبحوث الإنسانية والاجتماعية والتربوية (مجلة علمية محكمة)

(2)"I know," she began slowly, "that this is no more than it is. But I won't be spoken to like that."

"I'm sorry. It was wrong of me...."

"Just because you feel guilty, I've nothing to feel-"

"Yes, I'm sorry, I have no..."

"Because you can go if you-"

"I don't want to go. I want you." (White Teeth, P. 147)

In the previous extracts, the offenders take responsibility by overtly admitting that the situation is their fault. In extract (1), Samad expresses his apology for kissing Poppy Hurt-Jones. He blames himself for what he has done. He remembers his wife and his children. In extract (2) Samad apologies to Poppy Hurt-Jones for discussing the physical, not the metaphysical, matters of their relationship.

\subsubsection{Expressing Self-Deficiency}

Consider the following extracts:

(1)"What's the proof on about?" asked Mackintosh.

"No thing," said Samad."I'm afraid I was not 'on' about

anything; I was just talking, talking, just trying the shooting of

the breeze as they say..."(White Teeth, P. 72)

In the previous extract, the offender takes responsibility by overtly admitting that the situation is his or her fault. In this extract, Samad apologizes to Mackintosh. He says that he is just talking in order to try the shooting of the breeze. He wants to end the controversy that he and Mackintosh could fight together as British subjects. 
مجلة وادي النيل للاراسات والبحوث الإنسانية و الاجتماعية والتربوية (مجلة علمية محكمة)

(ISSN : 2536 - 9555)

\subsubsection{Recognizing the Other Person as Deserving Apology}

By using this strategy the offender doesn't attempt to minimize or deny the responsibility of the offence s/he makes. $\mathrm{S} / \mathrm{He}$ admits the offence done.Some of the apologies included in this category contain phrases that make this acknowledgment explicit, such as "Right. Of course," "Well, anyway", "All right, then," and "Right. Well ..." Consider, for example, the following extracts:

(1)"He's a register, Archibald, you old flake," said his friend Samad," Not a catholic priest."

"Right.Of course. Sorry. Nervous."(White Teeth, P. 42)

(2) "Sam? Sam? You don't look right, Sam. Please, they'll be here in a minute ... Sam?

"Don't call me Sam," he growled," I'm not one of your English matey-boys. My name is SamadMiahIqbal. Not Sam. Not Sammy ... It is Samad."

"Well, anyway," said Samad, "I'm glad you're here because I wanted to tell you that I am the worse for wear, Lieutenant Jones."(White Teeth, P. 94)

As it is obvious in the previous extracts, the apologizers admit the offence done. In extract (1), Archibald apologizes to Samad for calling the register who does the registration of the marriage a catholic priest. He justifies his apology on the ground that he is nervous. He expresses Samad's right to deserve apology by using the lexical items "right of course."In extract (2) Archibald apologizes to Samad for calling him Sam. Samad is angry because he doesn't want to be called Sam. His name is SamadMiahIqbal, not Sam, not Sammy. It is Samad.He expresses Samad's right to deserve apology by using the lexical items "Well, anyway."

\subsubsection{Expressing Lack of Intent}

Some of the sentences included in this apology and that make the acknowledgment of the offence explicit are"I was just making 
Apology Strategies in the Interethnic Communication of Bicultural Fiction with Reference to Zadie Smith's Novel White Teeth Eman Taher Othman

مجلة وادي النيل للاراسات و البحوث الإنسانية والاجتماعية والتربوية (مجلة علمية محكمة)

an objection," "it's not that I want to embarrass you. I just would feel more -," "Oh no! No, I didn't mean that at all ....,"'I I didn't mean to embarrass you,"and "I didn't mean to ...."Consider the following extracts:

(1)"Ick-Ball! Jones! Get on with it. Do you see anyone else here chewing the fat?"

"I was just making an objection, sir-it is hard, sir, for a man to concentrate on his foxtrot. F's and his zebra z's ..."(White

Teeth, P.72)

(2)"I'm sorry, you are not married?"

"Divorced, actually, yes, divorce. I'm keeping the name."

"I see, you have my condolences, Miss Miniver. Now the matter I-"

"Umm, it's not Miss, either. I'm sorry, I have been married you see, so-it's not that I want to embarrass you, Mr. Iqbal. I just would feel more-if you-it's Ms.""Mzzz?"

"Ms."(White Teeth, P.107)

As it obvious in the previous extract, the offenders express their lack of intent for the offence done. In extract (1),Samad apologizes to Captain Dickinson-Smith for his participating in a conversation with Archie during work time. Samad doesn't want to be seen as neglecting his duties. He expresses his lack of intent by using the sentence "I was just making an objection, sir."In extract(2),Miniver apologizes to Samad for her demand to be called Ms, not Mrs or Miss. She is married, but at the same time she is divorced. She expresses her lack of intent by using the sentence "it's not that I want to embarrass you, Mr. Iqbal. I just would feel more-if youit'sMs."

\subsubsection{An Offer of Repair}

The strategy of "offer of repair" is usually used to offer a remedy for the physical or moral damage that the speaker has caused.In Blum-Kulka, et al. (1989:208), "an offer of repairmay be 
expressed either as a specific offer to repair "I will fix it" or left unspecified "I will see what l can do." Consider, for example, the following extract:

Consider, for example, the following extract:

(1) "Irie! This is my house and you are still a guest. I won't have that language in it!"

"Fine! I'll take it to the streets with the rest of the proletariat."(White Teeth, P. 197)

As it is obvious in the previous extract, the damage or inconvenience affected hearer can be compensated for. In this extract, Irie apologizes to Samad for using unaccepted language in the latter's house. Accordingly, she promises to "take it to the streets with the rest of the proletariat."Thus, she chooses to offer repair in a specified manner, intending this as an apology.

\subsubsection{Promise for Forbearance}

Considering the collected data, "promise for forbearance" is rarely used in the interaction between the British and Bangladeshis. Theyrarely use the strategy of "promise for forbearance" to apologize.

\subsection{Apology Modifiers in White Teeth}

Considering the collected data, modifiers are rarely used in the interaction between the British and the Bangladeshis. Theyrarely use modifiers when apologizing.

\subsection{Sequence of Apology Strategies in White Teeth}

In their interaction the British and the Bangladeshis combine one apology strategy with another. Data analysis shows that there is a combination of "expression of regret" and "explanation or account of situation."Consider, for example, the following extracts

(1)"Put that away."

"I have been thinking that I am buggered ... I realize this may come as a surprise to you-my upper lip-I'm afraid, is 


\section{Apology Strategies in the Interethnic Communication of Bicultural Fiction with Reference to Zadie Smith's Novel White Teeth Eman Taher Othman}

مجلة وادي النيل للاراسات والبحوث الإنسانية والاجتماعية والتربوية (مجلة علمية محكمة) not of the required stiffness-but the fact remains. I see only blackness. I'm a cripple, Jones. And my faith is crippled.(White Teeth, P. 94)

(2) "I see. And are there many pagans, Mrs. Owens, at Manor school?"

"Pagan-(I'm afraid)(I don't under-")

"It is very simple. The Christian calendar has thirtysevenreligious events. The Muslim calendar has nine ... And the first festival that must go, in my opinion, is this Harvest Festival business."

"I'm afraid, said Mrs. Owens,"Removing Christian festivals from the face of the earth is a little beyond my jurisdiction."(White Teeth, P. 107)

As it is obvious in the previous extracts, the apologizers make use of more than one apology strategy. In extract (1), Samad apologizes to Archie for refusing to put away his gun. He makes use of "expression of regret" and "explanation or account of situation." Samad expresses his regret by using the lexical item "afraid."He gives "explanation or account of the situation" by using the sentence "I'm a cripple." In extract (2), Mrs. Owensapologizes to Samad for her inability to understand Samad's observation that there many pagans at Manor School. She also apologizes to Samad for her refusal of his demand concerning the removing of Christian festivals. She makes use of "expression of regret" and "explanation or account of situation." She expresses his regret by using the lexical item "afraid". She gives an account of the situation by using the sentences "I'm a cripple" and "Removing Christian festivals from the face of the earth is a little beyond my jurisdiction."

Data analysis also shows that there is also a combination of "recognizing the other person as deserving apology", "expression of regret" and "explanation or account of situation".Consider, for example, the following extract: 
مجلة وادي النيل للاراسات والبحوث الإنسانية و الاجتماعية والتربوية (مجلة علمية محكمة)

(ISSN : 2536 - 9555)

(1)"He's a register, Archibald, you old flake," said his friend

Samad," Not a catholic priest."

"Right.Of course.Sorry.Nervous."(White Teeth, P. 42)

In the previous extract, Archibald apologizes to Samad for calling the register who performs the registration of the marriage a catholic priest. He recognizes the other person as deserving apology by using the lexical "Right." He expresses his regret by using the lexical "sorry". He justifies the offence done on the ground that he is "nervous."

- There is a combination of "expressing of regret," "expressing lack of intent," and "expressing self-deficiency."Consider, for example, the following extract:

(1)"What's the proof on about?" asked Mackintosh.

"No thing," said Samad."(I'm afraid) (I was not 'on' about anything;)(I was just talking, talking,just trying the shooting of the breeze as they say...")(White Teeth, P. 72)

In this extract, Samad apologizes to Mackintosh. He says that he is just talking in order to try the shooting of the breeze. He wants to end the controversy that he and Mackintosh could fight together as British subjects. Samad expresses his regret by using the lexical "afraid". He expresses his lack of intent of the offence done by using the sentence "I was not 'on' about anything." As for "expressing self-deficiency", Samad uses the sentence "I was just talking, talking, just trying the shooting of the breeze as they say..."

Furthermore, there is a combination of "request for forgiveness" and "explanation or account of situation." Consider, for example, the following extracts:

(1) "Look like hell" snorted Gozan's nephew. "Everything looks like hell!"

"Pardon him. He feels strongly because he is young ...Lieutenant Jones,"Said Gozan(White Teeth, P. 92) 
Apology Strategies in the Interethnic Communication of Bicultural Fiction with Reference to Zadie Smith's Novel White Teeth Eman Taher Othman

مجلة وادي النيل للاراسات و البحوث الإنسانية والاجتماعية والتربوية (مجلة علمية محكمة)

(2) "You took your time," said Archie as Magid approached their table.

"Pardon me please. I was speaking with your friend, Michael."(White Teeth, P. 374)

In the previous extracts, the apologizers make use of "request for forgiveness" and "explanation or account of situation." In extract (1), for example,Gozanapologizes to Lieutenant Jones for the bad behavior of his nephew. He expresses his request for forgiveness by using the lexical item "pardon". He justifies the offence done on the ground that "he feels strongly because he is young." In extract (2), Magid apologizes to Archie for being late. He expresses his request for forgiveness by using the lexical item "pardon". He justifies the offence done on the ground that he was speaking with Archie friend, Michael.

There is also a combination of "expression of regret", "explanation or account of situation" and "expressing lack of intent". Consider, for example, the following extracts:

1) "I'm sorry? You are not married?

"Divorced, actually, yes, divorced."

"I see. You have my condolences.Miss Miniver Now, the matter I --"

"Umm, it's not Miss, either. (I'm sorry.) (I have been married you see), so -"it's not that I want to embarrass you, Mr. Iqbal.)I just would feel more-if you-it's Ms." (White Teeth, P.197)

(2) "Who will pray with me?" "Sorry Sam," came a muffled voice (Archie had his head in the closet). "Not really my cup of tea, either. Never been a church man. No offense. (White Teeth, P. 189) 
مجلة وادي النيل للاراسات والبحوث الإنسانية والاجتماعية والتربوية (مجلة علمية محكمة)

(ISSN : 2536 - 9555)

As it is obvious in the previous extracts, the apologizers make use of "expression of regret", "explanation or account of situation" and "expressing lack of intent". In example (1), Miniver apologizes to Samad for her demand to be called Ms, not Mrs or Miss. She is married, but at the same time she is divorced. She expresses her regret by using the lexical item "sorry." She gives an account of the situation on the ground that she has been married. She expresses her lack of intent by using the sentence "it's not that I want to embarrass you, Mr. Iqbal. I just would feel more-if youit'sMs. "In extract (2),Archibald apologizes for not praying with Samad to avoid the tidal wave. He expresses his regret by using the lexical item "sorry. "He gives "account of situation" on the ground that he has never been a church man. He expresses his "lack of intent" by using the phrase "no offence."

There is a combination of "expression of regret" and "accepting the blame". Consider the following extract:

(1) "I know," she began slowly," that this is no more than it is. But I won't be spoken to like that."

"I'm sorry.It was wrong of me..."

"Just because you feel guilty, I've nothing to feel..."(WhiteTeeth, P. 147)

In the previous extract,Samad apologies to Poppy Hurt-Jonesfor discussing the physical, not the metaphysical, matters of theirrelationship. Samad employ more than one apology strategy. He expresses his regret by using the lexical item "sorry." Furthermore, he accepts the blame by using the sentence "It was wrong of me."

There is a combination of "expressing the other person as deserving apology" and a "request for forgiveness." Consider, for example, the following extract:

(1) "No, Archie. That is a common mistake. The truth doesn't depend on what you read."

"All right, then: Pande. What did he achieve? All he did was start a mutiny - too early, mind, before the agreed 
Apology Strategies in the Interethnic Communication of Bicultural Fiction with Reference to Zadie Smith's Novel White Teeth Eman Taher Othman

مجلة وادي النيل للار اسات والبحوث الإنسانية والاجتماعية والتربوية (مجلة علمية محكمة)

date-and excuse my French, but that's a fucking disaster in military terms."(White Teeth, P. 209)

As it is obvious in the previous extract, Archibald apologizes to Samad for denying the achievements of his greatgrandfather MangalPande. He expresses Samad's right to deserve apology by using the phrase "All right,then."He expresses his request for forgiveness by using the lexical item"excuse."

Finally, there is a combination of "expressing lack of intent" and "expression of regret".Consider, for example, the following extract:

(1)"Well, why don't you get in the fucking bath with the fucking jeans on and see what happens?"

Magid turned the other cheek.

"Umm, I didn't mean to ... Oh shit ....Sorry ....Look ... I

don't know .... You're just so ....have you heard from

Millat?"(White Teeth, P. 354)

As it is obvious in the previous extract, Magid apologizes to Irie for interrupting her while she is working. He expresses his lack of intent by using the sentence"Umm, I didn't mean to...." He expresses his regret by using the lexical item "Sorry."

\subsection{Quantitative Analysis of Apology Strategies in White Teeth}

An attempt at finding the frequency of different types of apology strategies in White Teethis done below.

\begin{tabular}{|l|c|c|}
\hline Apology Strategy & Frequency & Percent \\
\hline 1. Expression of Apology. & & \\
a. Expression of Regret. & 13 & $21 \%$ \\
b. Offer of Apology. & 1 & $2 \%$ \\
c. Request for Forgiveness. & 8 & $13 \%$ \\
\hline 2. Explanation or Account of & 20 & $32 \%$ \\
\hline
\end{tabular}


مجلة وادي النيل للاراسات والبحوث الإنسانية والاجتماعية والتربوية (مجلة علمية محكمة)

(ISSN : 2536 - 9555)

\begin{tabular}{|l|c|c|}
\hline Situation. & & \\
\hline 3.Acknowledgment of & 2 & $3 \%$ \\
Responsibility. & 1 & $2 \%$ \\
$\begin{array}{l}\text { a. Accepting the Blame. } \\
\text { b. Expressing Self-Deficiency. } \\
\begin{array}{l}\text { c. Recognizing the Other } \\
\quad \text { Person as Deserving }\end{array}\end{array}$ & 6 & $10 \%$ \\
$\quad \begin{array}{l}\text { Apology. } \\
\text { d. Expressing Lack of Intent. }\end{array}$ & 10 & $16 \%$ \\
\hline 4. Offer of Repair. & 1 & $2 \%$ \\
\hline 5. Promise for Forbearance. & 0 & $0 \%$ \\
\hline Total & 62 & $100 \%$ \\
\hline
\end{tabular}

Table 1: Types and Frequency of Apology Strategies Used by the British and Bangladeshis in White Teeth.

Table (1) shows "expression of apology" has the frequency of 22 out of the 62 , that is $36 \%$ of all the apology strategies, the strategy of "explanation or account of situation" has the frequency of 20 out of the 62 , that is $32 \%$, the "acknowledgment of responsibility" has the frequency of 19 out of 62 , that is nearly $31 \%$, the "offer of repair" has the frequency of 1 out of 62 , that is nearly $2 \%$.

Another aspect that Table (1) shows is that the most frequently employed strategy is "expression of apology" with a frequency of 22 out of 62 , that is $36 \%$ of all the apology strategies employed, the second most frequently employed strategy is "explanation or account of situation" with a frequency of 20 out of 62 , that is $32 \%$ of all the apology strategies employed, followed by "acknowledgment of responsibility" with the frequency of 19 out of 62 , that is nearly $31 \%$, and finally the "offer of repair" has the frequency of 1 out of 62 , that is nearly $2 \%$.

Thus, as Table (1) shows, there is a preference for explicit "expression of apology," namely "expression of regret,""offer of apology," and "request for forgiveness." In Ohlstain and Cohen (1983), Blum-Kulka, et al. (1989) and Holmes (1990), apologizing by an IFID is usually the first and most direct manner of expressing 
Apology Strategies in the Interethnic Communication of Bicultural Fiction with Reference to Zadie Smith's Novel White Teeth Eman Taher Othman

مجلة وادي النيل للار اسات والبحوث الإنسانية والاجتماعية والتربوية (مجلة علمية محكمة)

remorse, whereby the offender uses one of the set of formulaic, routinized performative verbs ("(be)sorry, excuse, apologize, forgive, regret, pardon") to apologize.Moreover, Table (1) shows that there is a preference for the category"explanation or account of situation" that attempts to minimize or deny the responsibility of the speaker. In Blum-Kulka, et al. (1989: 208), "explanation or account of situation"is "the offender's way of placating the face using external forces ...over which s/he has no (or very little) control."

\subsection{Conclusion}

This study provides a socioprgmatic analysis of the interethnic communication between the British and the Bangladeshis in Zadie Smith's novel White Teeth. The speech act of apology is the object of the present study.In order to answer the research question set forth for this study, the data collected were analyzed both qualitatively and quantitatively. The qualitative analysis is carried in terms of what kinds of strategies speakers use most often when apologizing. Consequently, a number of basic categories of apologies have been set in order to analyze the data. The categories are adapted from Olshtain and Cohen (1983). The examples are taken from the collected data.The quantitative analysis allows for a more in depth look at the different strategies that speakers use in order to apologize in different situations. Therefore, an attempt at finding the frequency of different types of apologies in the three novels is done.

The general results of this study have shown that the British and the Bangladeshis in White Teeth use a big number of strategies to apologize. However, there is a preference of a strategy over another. Data analysis has shown that the choice of apology strategies depends on both the cultural background of the speaker and that of the hearer. 
مجلة وادي النيل للاراسات و البحوث الإنسانية والاجتماعية والتربوية (مجلة علمية محكمة)

(ISSN : 2536 - 9555)

\section{References}

Bergman, Marg L., Kasper, Gabriele (1993) "Perception andperformance in native and nonnative apology." In G. Kasper and S. Blum-Kulka, (eds.), Interlanguage Pragmatics. Oxford: Oxford University Press, 82-107.

Brown, Steven \&Attardo, Salvatore (2000) Understanding Language Structure, Interaction, and Variation: An Introduction to Applied Linguistics and Sociolinguistics for Nonspecialists. Michigan:Michigan University Press.

Davies, Bethan, Merrison, Andrew John \& Goddard, A. (2007) "Institutional Apologies in UK Higher Education: Getting Back into the Black before Going into the Red." Journal of Politeness Research, 3, 39-63.

Deutschmann, Mats (2003) Apologizing in British English. Unpublished Doctoral Dissertation, Umea Universiteit, Ummea.

Fraser, Bruce (1981) "On apologizing." In Florian Coulmas (ed.) Conversational Routine: Explorations in Standardized Communication Situations and Prepatterned Speech. The Hague: Mouton, 259-271.

Goffman, Erving (1972) "On face-work: An analysis of Ritual Elements in Social Interaction."In J. Laver and S. Hucheson (eds.) Communication in face to face interaction. Harmonds worth: England: Penguin, 179-196

Holmes, Janet (1990) Apologies in New Zealand English. Language in Society, 19(2): 155-199.

Longman.

Lazare, Aaron (2004) On apologizing. Oxford: Oxford University Press. 
Apology Strategies in the Interethnic Communication of Bicultural Fiction with Reference to Zadie Smith's Novel White Teeth Eman Taher Othman

مجلة وادي النيل للار اسات والبحوث الإنسانية والاجتماعية والتربوية (مجلة علمية محكمة)

Márquez-Reiter, Rosina (2000) Linguistic politeness in Britain and Uruguay: Acontrastive Study of Requests and Apologies. Philadelphia: John Benjamins.

Nureddeen, Fatima Abdurahman (2008) "Cross-cultural pragmatics: Apology

strategies in Sudanese. " Journal of Pragmatics 40, 279-306.

Olshtain, Elite \& Cohen, Andrew (1983) "Apology: A speech act set." In Nessa

Wolfson \& Elito Judd (eds.), Sociolinguistics and Language Acquisition. Rowley, Mass: Newbury House, 18-36.

Owen, Marion (1983) Apologies and Remedial Interchanges: A Study of

Language Use in Social Interaction. Berlin: Mouton Publishers

Partridage, Eric (1977) Origins: A Short Etymological

Dictionary of Modern English. New York: Macmillan.

Smith, Zadie (2000) White Teeth. New York: Vintage Books.

Trosborg, Anna (1994) Request, Complaint, and Apologies. New York: Mouton de Gruytar. 